William R. Emmons is an economist and Frank A. Schmid is a senior economist at the Federal Reserve Bank of St. Louis. William Bock and Judith Hazen provided research assistance.

\section{Bank Competition and Concentration: Do Credit Unions Matter?}

\author{
William R. Emmons and \\ Frank A. Schmid
}

Competition between banks and credit unions is interesting, in part, because it entails a forprofit sector (commercial banks) competing with a not-for-profit sector (credit unions). In addition, the distribution of market shares across financial intermediaries with different clienteles, service offerings, and cost structures may have implications for overall financial-sector efficiency. This article examines annual county-level observations of the concentration of commercial-bank depositmarket shares and household participation in occupational credit unions for the period between 1989 and 1996. We find empirical evidence that banks and credit unions directly affect each other's competitive positions in local deposit markets.

Previous research (Emmons and Schmid, 1999a) finds a link between the concentration of local commercial-bank deposit shares (as measured by the Herfindahl index) and indicators of credit-union efficiency (wage expense) and risk-taking (loan-loss allowances). ${ }^{1}$ In addition, higher commercial-bank deposit concentration is associated with higher household participation rates-the fraction of those who are eligible and who choose to join - at credit unions (Emmons and Schmid, 1999b). Thus, competitive conditions among banks appear to influence the behavior of credit unions and their potential members. It has not been clear, however, whether the effects also run in the other direction-that is, whether credit unions affect the structure of local deposit markets that are dominated by commercial banks and thrifts.

The purpose of this article is to investigate the two-way interaction between banks and credit unions in local markets. Emmons and Schmid (2000) develop and analyze a dynamic model of spatial competition between banks and credit unions. There is no consensus in the literature about how best to model competition in financial services, so the model in that study provides a framework for making comparisons with other work. In this analysis, we provide a brief overview of the model in our working paper and provide empirical results from estimations of response functions of the local commercial-banking sector and of households (who comprise the credit unions).

\section{CREDIT UNIONS AND COMPETITIVE ANALYSIS OF LOCAL BANKING MARKETS}

There is a large and growing literature that investigates competition among banks (for example, see Berger, Demsetz, and Strahan, 1999; Amel and Hannan, 1998; or Prager and Hannan, 1998). Much less research focuses on the interactions between credit unions (or thrift institutions) and banks (Hannan and Liang, 1995). This section briefly discusses the bank-competition literature and asks whether credit unions are important for banking competition.

\section{Banking Market Concentration, Prices, and Profits}

Mergers among depository institutions and steady expansion of credit unions have been two hallmarks of the U.S. financial landscape in the 1980s and 1990s, but simply acknowledging these trends is not sufficient to characterize the evolution of competitive conditions in local deposit markets. The number of commercial-bank charters in existence has declined by between 3 and 5 percent annually since 1988, resulting in a nine-year (1988-97) cumulative disappearance of 33 percent of all bank charters (Berger, Demsez, and Strahan, 1999, Tables 1 and 2). Mergers accounted for about 84 percent

\footnotetext{
${ }^{1}$ A Herfindahl index is the sum of squared market shares, ranging between zero and one. In the hypothetical case of perfect competition in which no competitor has more than a negligible market share, the Herfindahl index is marginally above zero. In the monopoly case, the Herfindahl index takes on its maximum value of one.
} 
of disappearances and failures for 16 percent. Deposit-market concentration, however, actually declined slightly during this period. Average commercial-bank deposit Herfindahl indexes in metropolitan statistical areas fell from 0.2020 to 0.1949 , and those in nonmetropolitan counties fell from 0.4316 to 0.4114 (Berger, Demsetz, and Strahan, 1999, Table 1). Meanwhile, credit-union membership grew more than 38 percent in the decade ending in 1996, while the country's population grew about 10 percent (U.S. Treasury, 1997, p. 24).

Does market concentration matter for prices and profits? In a non-banking context, Tirole notes that, "Most cross-sectional analyses find a weak but statistically significant link between concentration and profitability (1988, p. 222)." With regard to banking markets, Gilbert (1984) concluded in an early review of the empirical literature that the economic significance of market concentration by banks before deregulation was very difficult to assess, not least because of the poor quality of much of the empirical research. More recently, Shaffer (1992) summarized the (lack of) current consensus by stating that the degree to which banking market structure matters for competition and performance is "a hotly debated topic."

The predominant empirical approach to banking competition during the last several decades has been the so-called SCP (Structure-Conduct-Performance) paradigm. The SCP approach remains the dominant approach in the regulatory analysis of antitrust issues in banking (Kwast, Starr-McCluer, and Wolken, 1997). This approach presumes that measures of banking market structure, including measures of market concentration, are good indicators of the intensity of competition that occurs ("conduct") (Scherer and Ross, 1990, pp. 4-7). The intensity of competition influences the price for financial services, which are, in turn, assumed to determine firms' profits ("performance"). In a nutshell, the higher the concentration in the local banking market, the higher the prices are for financial services, and consequently the higher the banks' profits. The policy implication is that higher market concentration is associated with lower social welfare and, therefore, higher concentration is undesirable. However, the sources of differential levels of market concentration are left unexplained.

Numerous banking studies demonstrate statistical relationships that are consistent with some aspects of the SCP paradigm, at least in a static context (Berger and Hannan, 1989; Neumark and
Sharpe, 1992; Hannan, 1997; Prager and Hannan, 1998; Amel and Hannan, 1998). On the other hand, some evidence is inconsistent with the predictions of this framework (Shaffer, 1989). Moreover, some of the evidence that is consistent with the predictions of the SCP paradigm is subject to a different interpretation. For example, the link between market structure and profitability may be spurious in the sense that an important variable is omitted. Some firms may have large market shares simply because their costs are lower than those of their competitors (Demsetz, 1973; Berger, 1995). This is a desirable outcome, not one that reduces social welfare.

It is not the purpose of this paper to test the SCP paradigm. We do not observe financial-services prices directly (corresponding to the "conduct" element), for example, and our measure of performance is not bank profits. The SCP framework is related to our theoretical model, however, so it is useful to outline what our model has in common with the SCP paradigm as well as to clarify those respects in which they differ.

The SCP paradigm is predominantly an empirical approach and has been applied most often without explicit reference to a theoretical model of competition. Consequently, the link between higher prices and higher profitability usually is viewed as an empirical question. It is precisely this link between prices and profitability, however, that is questionable on theoretical grounds. Even if higher concentration leads to higher prices for financial services (and consequently to a decline in demand), this does not necessarily translate into higher bank profits. With free entry and exit, the zero-profit condition may hold even in a world of oligopolistic competition. If oligopolistic competitors operate with fixed costs-a reasonable assumption in most cases-then higher concentration may coexist with higher prices without violating the zero-profit condition. In such a case, the higher price would be caused by higher average costs due to lower market output. ${ }^{2}$ Thus, while users of the SCP paradigm typically draw the conclusion that higher prices (caused by higher concentration) lead to higher profitability, this conclusion is not warranted on purely theoretical grounds. It remains

\footnotetext{
${ }^{2}$ It is important to differentiate between fixed costs and sunk costs (Tirole, 1988, pp. 307-8). Fixed costs that are recoverable are not sunk and do not function as a barrier to entry. Only sunk costs confer market power.
} 
an empirical question whether higher concentration actually leads to higher profitability-that is, whether barriers to entry or exit matter.

\section{Credit Unions in the Analysis of Banking Competition: Do They Belong?}

The primary focus of bank antitrust enforce ment in the merger-review process carried out by the Antitrust Division of the Department of Justice and by federal bank regulators (the Federal Reserve, the Office of the Comptroller of the Currency, and the Federal Deposit Insurance Corporation) is "the availability of banking services, including loans and credit, to small and medium-sized businesses" (Nanni, 1998, p. 193). This focus on the availability of small-business credit means that credit unions, which serve the household sector almost exclusively, are ignored routinely for purposes of regulatory analysis of banking market competition. Compounding the problem of defining and measuring the relevant market, the only comprehensive localmarket data available are annual observations of commercial-bank and BIF-insured thrift deposits. ${ }^{3}$ Deposit data do not differentiate between commercial and retail ownership (i.e, business and household deposits), so comparisons of depository institutions with different mixes of deposit customers are necessarily imprecise. ${ }^{4}$

Direct empirical evidence that credit unions matter in banking markets has been difficult to find. Amel and Hannan (1998) conclude on the basis of empirically estimated residual deposit supply elasticities that commercial banks in alocal market continue to be their own most relevant competitors. That is, it does not appear that non-local or non-bank financial institutions such as out-of-market banks, credit unions, other thrift institutions, finance companies, or providers of money-market mutual funds are important determinants of deposit rate-setting behavior by banks.

There is at least some indirect evidence that credit unions matter to banks, however. Bankers themselves frequently complain about (possibly unfair) competition from credit unions. ${ }^{5}$ Collectively, banks have spent large sums of money lobbying Congress to inhibit credit-union expansion (see Emmons and Schmid, 1999b). Thus, there is at least a reasonable presumption that banks view credit unions as competitors-actual or potentialin at least some of their market segments, such as the market for household deposits.

\section{A MODEL OF BANK-CREDIT UNION COMPETITION}

The theoretical model in Emmons and Schmid (2000) shows that an exogenous increase in commercial-banking costs leads to higher bank concentration (as measured by the Herfindahl index), which, in turn, results in higher prices for the financial services banks offer. In response, households who were bank customers migrate to credit unions, increasing credit-union participation rates and shrinking the residual household market served by banks-an additional (endogenous) source of higher bank concentration. This feedback, in turn, unleashes a continuing endogenous adjustment process of higher bank concentration and increasing credit-union participation. If a local deposit market is in a stable equilibrium, this adjustment process eventually comes to a halt with both sectors retaining positive market shares; if not, one sector or the other is driven out completely. Likewise, an external shock that leads to higher participation rates at credit unions-such as legislative changes favorable to credit unions - unleashes the dynamic adjustment process outlined above. Shocks that reduce bank concentration or credit-union participation rates initiate processes of dynamic adjustment in the opposite direction.

This article presents the empirical results of two hypotheses derived from the theoretical model in Emmons and Schmid (2000):

Hypothesis 1: Higher deposit-market concentration leads to higher credit-union participation. Hypothesis 2: An increase in credit-union participation leads to higher deposit-market concentration.

The following section outlines the dynamic interactions highlighted by the model.

The Dynamic Model. In this section, we cast the model's hypotheses as a pair of response functions. These response functions allow for a one-

\footnotetext{
${ }^{3}$ The Bank Insurance Fund (BIF) of the FDIC insures some thrift institutions while other thrifts are covered by the FDIC's Savings Association Insurance Fund (SAIF).

${ }^{4}$ This shortcoming of the data means that evidence of interaction between commercial banks and other types of limited-purpose depository institutions-such as credit unions-may be obscured by the inclusion of markets in which they do not compete directly. The evidence reported in this article, therefore, understates the true extent of credit unions' effects on banks and may overstate the effects of banks on credit unions.

${ }^{5}$ Credit unions are exempt from federal income taxes, which allows them to operate with low costs of capital.
} 


\section{Figure 1}

\section{Dynamic Response Model}

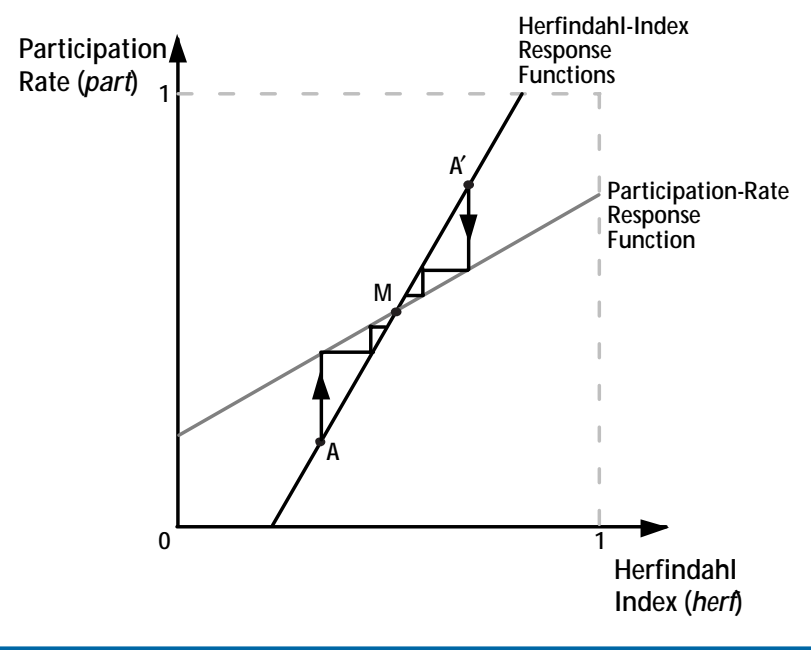

period response lag by both households (who comprise credit unions) and commercial banks. The first response function characterizes the behavior of households $(\mathrm{HH})$, who may join and participate in the governance of occupational credit unions. The second response function characterizes the behavior of the commercial-banking sector, members of which are governed by shareholders:

$$
\begin{aligned}
& \operatorname{part}_{t}=r^{H H}\left(\text { herf }_{t-1}\right) \\
& \text { herf }_{t}=r^{C B}\left(\text { part }_{t-1}\right),
\end{aligned}
$$

where $\mathrm{r}^{\mathrm{HH}}$ is the response function of households and $r^{C B}$ is the response function of commercial banks, and part and herf are the household participation rate (number joining divided by number eligible) in occupational credit unions and the commercial-bank Herfindahl index, respectively.

Equation 1 says that the level of household participation in occupational credit unions reacts with a one-period lag to the degree of concentration in the commercial-banking sector. As described above, the link between higher (lower) concentration and higher (lower) credit-union participation is a higher (lower) price for financial services offered by banks. Equation 2 states that the concentration of the commercial-banking sector responds with a one-period lag to the level of household participation in credit unions.

\section{Solution to the Dynamic Model and}

Stability Conditions. This section outlines the solution to the dynamic model described by equations 1 and 2 . Figure 1 presents a graphical illustration of a stable equilibrium. ${ }^{6}$ In brief, an interior equilibrium is stable if (and only if) the commercialbank Herfindahl-index response function, $r^{\mathrm{CB}}$, is steeper than the participation-rate response function, $\mathrm{r}^{\mathrm{HH}}$ (as in Figure 1). If the local financial-services sector finds itself off the equilibrium value, $M$, say, at points $A$ or $A^{\prime}$, an adjustment process takes the sector back toward the equilibrium, M (see arrows). ${ }^{7}$

Comparison of Equilibria. Exogenous shifts in the response functions might be due to technology shocks or to changes in legislation. For example, the commercial-bank Herfindahl-index response function could shift to the right (see Figure 2). This could occur if the banks' fixed costs of production increase, while all other exogenous variables remain unchanged. At the credit-union participation rate prevailing under the original equilibrium, $\mathrm{M}$, the market cannot accommodate the current number of banks if industry profits remain zero. To restore a situation with zero profits, the number of banks must decline, which increases concentration. Higher concentration raises the price of a unit bundle of banking services, which leads to an increase in the credit-union participation rate. This corresponds to a shift of the commercialbank Herfindahl-index response function to the right. The new equilibrium is located at point $\mathrm{M}^{\prime}$, which signifies higher banking-market concentration and higher credit-union participation.

Another example of an exogenous shift is an upward movement of the participation-rate response function (see Figure 3). This could occur if, for instance, the credit unions' fixed costs of production decrease, while all other exogenous variables remain unchanged. The average costs of production for credit unions now will be lower, leading to

\footnotetext{
${ }^{6}$ Emmons and Schmid (2000) also formally analyze the stability of the (interior) equilibrium.

${ }^{7}$ Another possibility exists, however. If the participation-rate response function, $\mathrm{r}^{\mathrm{HH}}$, is steeper than the commercial-bank Herfindahl-index response function, $\mathrm{r}^{\mathrm{CB}}$, the local financial-services sector will diverge even further from the equilibrium, $M$. Starting from point $A$, the banking sector will crowd out the credit unions completely, leading to a participation rate part $=0$. Starting from point $A^{\prime}$, credit unions will drive out the banks, which leads to a participation rate part $=1$. We do not examine counties that are in these situations.
} 
a decline in the price they charge for a unit bundle of financial services. As a consequence, marginal households - those that were close to joining but had not done so-will join their credit union, increasing the participation rate at the prevailing price charged by banks (as determined by the degree of banking-sector concentration). Such an increase in the credit-union participation rate corresponds to an upward shift of the participation-rate response function. The new equilibrium is located at point $\mathrm{M}^{\prime}$, which displays higher banking-market concentration and higher credit-union participation.

The Credit Union Membership Act of 1998 may constitute an actual example of the latter type of shift (our sample ends in 1996, so we cannot evaluate this event directly). Among other things, the Act makes it easier for credit unions to adopt multiple-common-bond charters. Although multiple common bonds were not unknown before 1998, there was some uncertainty about the legality of these organizational forms. In fact, a Supreme Court ruling during early 1998 appeared to undermine many existing credit unions with multiple common bonds and to eliminate the possibility of new ones forming. As discussed in Emmons and Schmid (1999b), the 1998 Act reversed the essence of the Supreme Court decision and provided a solid legal foundation for credit unions with multiple common bonds. That article also investigated the likely consequences of the law for credit-union participation rates (for given prices charged by banks) by simulating a theoretical model. The simulation results show that the multiple-commonbond option tends to increase the fraction of households who join occupational credit unions at any given price charged by banks (see Emmons and Schmid, 1999b, Table 1). ${ }^{8}$ Translating these simulation results into the response function framework analyzed here implies that multiple-common-bond charters shift the participation- rate response function upward. As mentioned above, this causes higher credit-union participation rates and higher commercial-banking sector concentration. ${ }^{9}$

\section{DATA AND EMPIRICAL METHODS}

This section describes our data briefly and outlines the empirical methods we employ. An appendix describes our data sources and variable construction; for more details on the empirical methodology, see Emmons and Schmid (2000).

\section{Figure 2}

\section{Shift in Herfindahl-Index Response Function}

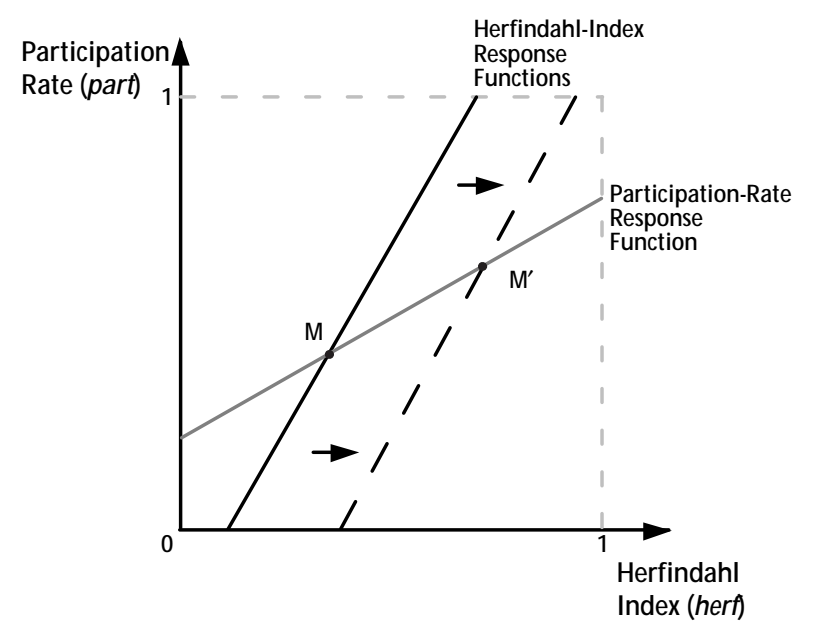

\section{Figure 3}

\section{Shift in the Participation-Rate Response Function}

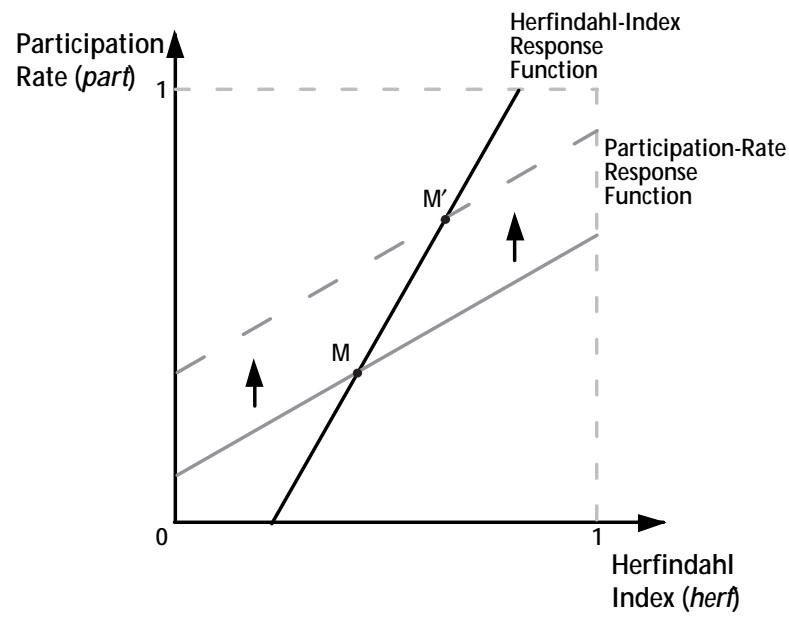

\footnotetext{
${ }^{8}$ The regression results presented by Emmons and Schmid (1999b, Table 5) cannot be interpreted as a positive influence of the multiplecommon-bond charters on the overall participation of (eligible) households in occupational credit unions. This is because the analysis includes credit unions that might not exist if there were no multiple-common-bond charters.

${ }^{9}$ The regression results presented in Emmons and Schmid (1999b, Table 6) cannot be interpreted as a positive influence of the multiplecommon-bond charter on the average operating costs of credit unions. This is because the analysis includes credit unions for which the operating costs of a single-common-bond charter might be prohibitively costly.
} 
Table 1

\section{Credit Union Type Of Membership (TOM) Codes}

\begin{tabular}{cl} 
TOM Code $^{1}$ & Type of Membership \\
\hline 4 & Educational \\
5 & Military \\
6 & Federal, state, local government \\
$10-15$ & Manufacturing \\
$20-23$ & Services \\
34 & Multiple group - primarily educational \\
35 & Multiple group - primarily military \\
36 & Multiple group - primarily federal, state, \\
& local government \\
$40-49$ & Multiple group - primarily manufacturing \\
$50-53$ & Multiple group - primarily services
\end{tabular}

${ }^{1}$ National Credit Union Association (NCUA), Instruction No. 6010.2, July, 28, 1995.

\section{Data}

The observations in our empirical analysis are annual credit-union participation rates and bank Herfindahl-index levels in individual counties (and independent cities). In other words, we aggregate information about credit unions and banks to the county level. We use these aggregated observations to estimate the response functions specified in the appendix of Emmons and Schmid (2000).

To construct our county-level variables, we begin with all federally chartered and federally insured occupational credit unions during the period 1989-96. Community, associational, and corporate credit unions also exist, but occupational credit unions are by far the dominant type of retail credit union, holding almost 85 percent of member deposits (U.S. Treasury, 1997, p. 19). Table 1 shows the Type of Membership (TOM) codes that applyto the occupational credit unions in our dataset. These include credit unions with single and multiple common bonds. We do not examine community, associational, or corporate credit unions because they are less numerous than occupational credit unions and their members and purposes may differ substantially. Including these diverse types of credit unions would make interpretation of our results more difficult.

Table 2 provides a breakdown of our credit-union dataset in each year according to the type of membership (TOM) group. The most common type (single and multiple-common bonds) is manufacturing, followed by government authorities. The number of credit unions covered remains fairly constant at just over 5,000 during each year between 1989 and 1996, with a pooled total of 41,329, before screens are applied on the county level that reduce this number slightly.

Table 3 summarizes the bank-concentration measure we use, the Herfindahl index of bank deposit shares calculated at county level, for each of the years in our sample. The median and mean values of the annual county Herfindahl index levels decline during our sample period, which is consistent with the index values reported in Berger, Demsetz, and Strahan (1999, Table 1). The number of counties (and independent cities) for which values of the Herfindahl index are calculated, varies slightly from year to year because we discard counties that do not have any banks or credit unions in a given year.

Table 4 gives an overview of the credit-union participation rates at county level in our sample in each of the years we examined. As noted above, we discarded counties in which the participation rate was zero (i.e., there were no credit unions). We also discarded counties with participation rates equal to one for econometric reasons, as discussed in the appendix. The range of participation rates in the remaining counties is large, with a low of around 1 percent and a high of nearly 100 percent. The median and mean participation rates show a tendency to increase until they peak during 1994 around 59 percent. They then decline slightly, ending at values during 1996 that are still notably higher than 1989.

We use control variables in the regression to account for exogenous differences in the competitive environment in cross section and over time We control for county-level differences in urbanization patterns by using each county's population density during each year as an exogenous regressor. We also use state indicator variables in our regressions to proxy for cross-sectional differences in state law and regulation, and in economic activity. We use yearindicator variables to control for changes in economic activity and legislation at the national level over time. Further details are provided in the appendix.

\section{Empirical Methods}

We estimate an econometric model that pools annual observations from 1,062 counties (and independent cities) for the years 1989 through 1996. The dataset is unbalanced, which means that the number 
FEDERAL RESERVE BANK of ST. LOUIS

\section{Table 2}

\section{Distribution of Credit Unions by TOM Code ${ }^{1}$}

\begin{tabular}{lccccccccccc}
$\begin{array}{l}\text { TOM Code(s) } \\
\text { /Year }\end{array}$ & $\mathbf{4}$ & $\mathbf{5}$ & $\mathbf{6}$ & $\mathbf{1 0 - 1 5}$ & $\mathbf{2 0 - 2 3}$ & $\mathbf{3 4}$ & $\mathbf{3 5}$ & $\mathbf{3 6}$ & $\mathbf{4 0 - 4 9}$ & $\mathbf{5 0 - 5 3}$ & $\begin{array}{c}\text { Number of Observations } \\
\text { (Credit Unions) }\end{array}$ \\
\hline 1989 & 326 & 40 & 410 & 481 & 126 & 601 & 948 & 603 & 848 & 740 & 5,123 \\
1990 & 327 & 40 & 412 & 482 & 126 & 603 & 949 & 604 & 848 & 742 & 5,133 \\
1991 & 329 & 39 & 426 & 484 & 127 & 620 & 942 & 614 & 848 & 745 & 5,174 \\
1992 & 329 & 39 & 427 & 485 & 127 & 624 & 944 & 616 & 848 & 749 & 5,188 \\
1993 & 331 & 40 & 429 & 484 & 128 & 627 & 952 & 624 & 851 & 753 & 5,219 \\
1994 & 332 & 41 & 432 & 489 & 128 & 634 & 951 & 628 & 853 & 756 & 5,244 \\
1995 & 332 & 41 & 432 & 489 & 129 & 637 & 936 & 621 & 857 & 757 & 5,231 \\
1996 & 322 & 38 & 415 & 486 & 125 & 631 & 846 & 582 & 834 & 738 & 5,017
\end{tabular}

${ }^{1}$ Before eliminating 62 county-years for the reasons mentioned in the Appendix.

\section{Table 3}

\section{Descriptive Statistics for the Herfindahl Index ${ }^{1}$}

\begin{tabular}{ccccccc}
$\begin{array}{c}\text { Herfindahl Index } \\
\text { /Year }\end{array}$ & Minimum & Median & Mean & Maximum & $\begin{array}{c}\text { Standard } \\
\text { Deviation }\end{array}$ & $\begin{array}{c}\text { Number of Observations } \\
\text { (Counties) }\end{array}$ \\
\hline 1989 & 0.0344 & 0.2524 & 0.2707 & 0.9051 & 0.1280 & 1,035 \\
1990 & 0.0358 & 0.2510 & 0.2699 & 0.8806 & 0.1279 & 1,039 \\
1991 & 0.0360 & 0.2466 & 0.2661 & 0.8584 & 0.1259 & 1,040 \\
1992 & 0.0341 & 0.2507 & 0.2654 & 0.8489 & 0.1221 & 1,042 \\
1993 & 0.0444 & 0.2376 & 0.2611 & 0.8506 & 0.1218 & 1,037 \\
1994 & 0.0519 & 0.2304 & 0.2572 & 0.8500 & 0.1205 & 1,039 \\
1995 & 0.0512 & 0.2287 & 0.2532 & 0.8537 & 0.1178 & 1,047 \\
1996 & 0.0535 & 0.2263 & 0.2519 & 0.8357 & 0.1150 & 1,038
\end{tabular}

${ }^{1}$ After eliminating 62 county-years for the reasons mentioned in the Appendix.

of counties included is not the same during each year. The empirical model is a system of two "seemingly unrelated" equations, which are the response functions we derived in the theoretical model. These are, first, the participation-rate response function and, second, the Herfindahl-index response function. Both variables are bounded on the $(0,1)$ interval. We applied a logit transformation to ensure that these variables are unbounded, making a normal distribution of errors possible. For more details, see Emmons and Schmid (2000).

\section{Empirical Results}

Our empirical specifications are based on the predictions generated by the theoretical model in
Emmons and Schmid (2000) and outlined above. Our two main sets of findings can be summarized as follows. First, we find strong empirical support for the predictions of the model in Emmons and Schmid (2000) regarding dynamic interactions between banks and credit unions. In particular, we find statistically significant positive relationships between the current credit-union participation rate and the lagged value of the commercial-bank sector Herfindahl index in a particular county. In addition, we find a strong positive relationship between the current value of the banking-sector Herfindahl index and the lagged value of the creditunion participation rate in a given county. Second, we document shifts in both the credit-union partic- 


\section{Table 4}

Descriptive Statistics for the County Participation Rate ${ }^{1}$

\begin{tabular}{cccccc}
$\begin{array}{c}\text { Participation Rate } \\
\text { /Year }\end{array}$ & Minimum & Median & Mean & Maximum & $\begin{array}{c}\text { Standard } \\
\text { Deviation }\end{array}$ \\
\hline 1989 & 0.0423 & 0.5600 & 0.5696 & 0.9997 & 0.1913 \\
1990 & 0.0119 & 0.5567 & 0.5733 & 0.9959 & 0.1928 \\
1991 & 0.0411 & 0.5623 & 0.5726 & 0.9974 & 0.1908 \\
1992 & 0.0246 & 0.5787 & 0.5846 & 0.9964 & 0.1915 \\
1993 & 0.0375 & 0.5893 & 0.5937 & 0.9985 & 0.1895 \\
1994 & 0.0602 & 0.5897 & 0.5909 & 0.9998 & 0.1881 \\
1995 & 0.0367 & 0.5833 & 0.5824 & 0.9983 & 0.1889 \\
1996 & 0.0330 & 0.5776 & 0.5822 & 0.9987 & 0.1859
\end{tabular}

${ }^{1}$ After eliminating 62 county-years for the reasons mentioned in the Appendix.

\section{Table 5}

Participation-Rate Response Function

\begin{tabular}{llc} 
Independent Variable & Coefficient & t-statistic \\
\hline HERF (lagged) & 2.005 & $22.446^{* * *}$ \\
POPDENS & $2.648 \times 10^{-5}$ & $2.868^{* * *}$ \\
YEAR: 1990 & $7.935 \times 10^{-3}$ & 0.193 \\
YEAR: 1991 & $2.300 \times 10^{-2}$ & 0.434 \\
YEAR: 1992 & $1.231 \times 10^{-1}$ & $1.984^{* *}$ \\
YEAR: 1993 & $1.716 \times 10^{-1}$ & $2.774^{* * *}$ \\
YEAR: 1994 & $1.974 \times 10^{-1}$ & $3.177^{* * *}$ \\
YEAR: 1995 & $1.814 \times 10^{-1}$ & $2.910^{* * *}$ \\
YEAR: 1996 & $2.443 \times 10^{-1}$ & $3.912^{* * *}$ \\
CONSTANT & 2.572 & $14.358^{* * *}$ \\
\hline Wald-test & $27,679 * * *$ & \\
$\quad$ (nonconstant regressors) & & \\
Wald-test & $448.8 * * *$ & \\
$\quad$ (state-indicator variables) & & \\
Wald-test & $21.57 * * *$ & \\
$\quad$ (year-indicator variables) & & \\
Pseudo-R & 0.725 & \\
Pseudo-R ${ }^{2}$ adj. & 0.723 & \\
Number of observations & 8,317 &
\end{tabular}

$* *$ ****Significant at the 5/1-percent level (t-tests are two-tailed).

ipation rate response function (upward) and the commercial-bank Herfindahl index response function (leftward) during our sample period (1989-96).

\section{Model-Specification Tests}

Before presenting and discussing the main results of interest, this section reports values for goodness-of-fit measures and results of modelspecification tests.

Explanatory Power of the Model. We calculated two sets of measures of fit for the empirical model. The first measures were an $\mathrm{R}^{2}$ and an adjusted $R^{2}$ for the system of equations, which were 0.150 and 0.143 , respectively. The second type of goodness-of-fit measures was a pseudo $\mathrm{R}^{2}$ and an adjusted pseudo $R^{2}$ for each equation, both of which are reported in Tables 5 and 6 . The values for the pseudo $\mathrm{R}^{2}$ (and the adjusted pseudo $\mathrm{R}^{2}$ ) for the two equations were relatively close to each other, which indicates that the model provides about the same amount of explanatory power for each equation. ${ }^{10}$

We report three Wald tests in Tables 5 and 6. They compare the full model versus alternative specifications that exclude one set of variables at a time: all nonconstant regressors; the set of state indicator variables; and the set of year indicator variables. All Wald test values are statistically significant.

\footnotetext{
${ }^{10} \mathrm{~A}$ traditional $\mathrm{R}^{2}$ is not well-defined in a multiequation framework. Therefore, we calculated a pseudo $R^{2}$, which is the squared coefficient of correlation between the dependent variable and the "predicted value" for the independent variables (i.e., the sum of the dependent variable and the residuals). The adjusted pseudo $\mathrm{R}^{2}$ was obtained from the pseudo $R^{2}$ in the usual manner.
} 
Test for Stability. The dynamic model of competition between banks and credit unions rests on the two response functions discussed above, equa tions 1 and 2, that relate current-period behavior to lagged indicators of the other sector's behavior. We used the delta method (Greene, 1997) to test the equilibrium condition for our second-order difference equation, a stability condition. The value of this test under the hypothesis-that the two response functions have the same slope-was -9.59, which is statistically different from zero at the 1-percent level.

Participation-Rate Response Function. Table 5 presents the participation-rate response function results. As predicted, for given values of the control variables, credit-union participation rates are significantly higher in local banking markets that have more concentrated banking sectors in the previous year. Taking into account the logit transformation that was performed on both variables, it appears that an increase in the commercial-bank Herfindahl index of 0.01 increases the credit-union participation rate in a county by 0.0100 .

The results for the control variables used in the estimation also are interesting. Table 5 shows that participation rates are higher in counties with higher population densities. This indicates that urban and suburban areas have proportionately more credit-union members than rural areas have on average. It also means that credit-union participation tends to be associated with higher average per-capita income levels because metropolitan areas generally have higher average per-capita incomes than rural areas. As the year indicator variables show, participation rates generally increased during our sample period, holding banking market structure and population densities constant (subsequent years are measured against the baseline of 1989). This also constitutes evidence that credit unions are becoming more important competitors in the retail (i.e, household) financial-services market. A set of state indicator variables was used in the regressions that are not reported here.

Herfindahl-Index Response Function. Table 6 presents the Herfindahl-index response function results. As the model in Emmons and Schmid (2000) predicts, for given values of the control variables, concentration in the commercialbanking sector increases if the corresponding county has shown an increase in the credit-union participation rate during the previous year. Banks

\section{Table 6}

\section{Herfindahl-Index Response Function}

\begin{tabular}{lll} 
Independent Variable & Coefficient & t-statistic \\
\hline PART (lagged) & $3.428 \times 10^{-5}$ & $19.072^{* * *}$ \\
POPDENS & $-1.827 \times 10^{-5}$ & $-4.216^{* * *}$ \\
YEAR: 1990 & $1.762 \times 10^{-2}$ & 1.000 \\
YEAR: 1991 & $-5.196 \times 10^{-3}$ & -0.224 \\
YEAR: 1992 & $-2.196 \times 10^{-3}$ & -0.081 \\
YEAR: 1993 & $-4.058 \times 10^{-2}$ & -1.491 \\
YEAR: 1994 & $-7.905 \times 10^{-2}$ & $-2.922^{* * *}$ \\
YEAR: 1995 & $-9.305 \times 10^{-2}$ & $-3.476^{* * *}$ \\
YEAR: 1996 & $-8.716 \times 10^{-2}$ & $-3.237^{* * *}$ \\
CONSTANT & -1.271 & $-19.181^{* * *}$ \\
\hline Wald-test & $3,858^{* * *}$ & \\
$\quad$ (nonconstant regressors) & & \\
Wald-test & $1,443^{* * *}$ & \\
$\quad$ (state-indicator variables) & \\
Wald-test & $22.86 * * *$ & \\
$\quad$ (year-indicator variables) & \\
Pseudo-R ${ }^{2}$ & 0.860 & \\
Pseudo-R ${ }^{2}$ adj. & 0.859 & \\
Number of observations & 8,317 & \\
***Significant at the 1-percent level (t-tests are & \\
$\quad$ two-tailed). & & \\
& & \\
\end{tabular}

respond to losses in market shares with consolidation (for example, in-market mergers that result in the closing of branches), or simply with exit (for example, bank failures). Taking into account the logit transformation of the variables, we find that an increase in a county's credit-union participation rate by 0.01 increases the Herfindahl index in the county by 0.0035 . Thus, our evidence is consistent with the notion that credit unions are important competitors in the retail financial-services market in many localities.

Parameter estimates for the control variables given in Table 6 are consistent with findings from other studies of local banking markets. We find that bank concentration is significantly lower in more densely populated counties, as is well known from previous research. For example, the average Herfindahl index in Metropolitan Statistical Areas (MSA) was 0.1949 in 1997, while it was 0.4114 in non-metropolitan areas (Berger, Demsetz, and Strahan, 1999, Table 1). We also identify a signifi- 
Table 7

\section{Autonomous Changes in Concentration}

\begin{tabular}{ccc} 
Year & \multicolumn{2}{c}{$\begin{array}{c}\text { Autonomous changes relative to } \\
\text { the median values in 1989 } \\
\text { Herfindahl index }\end{array}$} \\
\hline 1990 & Participation rate & 0.0033 \\
1991 & 0.0020 & -0.0010 \\
1992 & 0.0057 & -0.0004 \\
1993 & $0.0300 * *$ & -0.0075 \\
1994 & $0.0417 * * *$ & $-0.0144 * * *$ \\
1995 & $0.0479 * * *$ & $-0.0169 * * *$ \\
1996 & $0.0440 * * *$ & $-0.0158 * * *$
\end{tabular}

$* * * * *$ Significant at the 5/1-percent level in two-tailed tests (based on Tables 5 and 6).

\section{Figure 4}

\section{Autonomous Changes in Participation and Concentration}

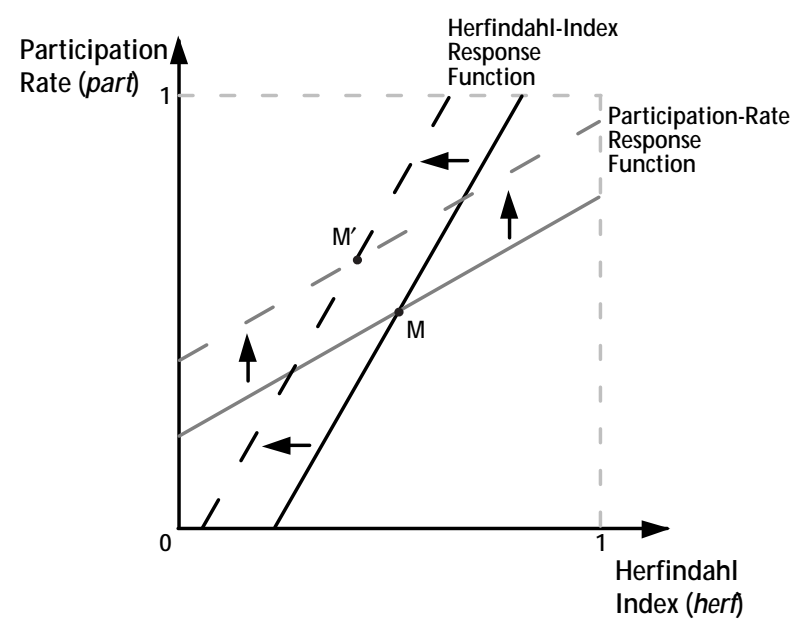

cantly declining level of local-market bank concentration during our sample period after controlling for credit-union participation rates and population density, which is consistent with other findings as well (Berger, Demsetz, and Strahan, 1999, Table 1). State indicator variables were used in this equation, too, but are not reported here.

Shifts in the Response Functions. Tables 5 and 6 shed some light on the reaction of participa- tion rates and commercial-bank Herfindahl index values to changes in lagged values of the other variable-i.e, movements along the response functions -as well as movements of the response functions themselves. Shifts of the response functions over time are reflected in changes in the population density and in the year-indicator variables. We define an autonomous change as one that is due to the year-indicator variables, which measure changes relative to the base period, the year 1989.

Table 7 provides estimates of the (cumulative) autonomous changes of the participation rate and the Herfindahl index. The autonomous changes in both the credit-union participation rate and the commercial-bank Herfindahl index were statistically significant for the later years of the 1990-96 period. After taking into account the logistic transformation we performed on the dependent variable, we find that participation rates increased by 0.0589 for reasons unrelated to the dynamic interaction of banks and credit unions or to changes in county population densities over time. Similarly, county-level bank Herfindahl index levels decreased by 0.0158 due to autonomous factors during the period 1989-96.

We summarize the quantitative effects discussed above in Figure 4. The figure shows the shifts of the response functions in the directions indicated by the data displayed in Table 7. The original equilibrium lies at point $M$. Depending on the relative strengths of the two shifts, the new equilibrium may exhibit a higher participation rate and a lower Herfindahl index, as shown in the new equilibrium, point $\mathrm{M}^{\prime}$. This is consistent with the 1.8percentage-point increase actually observed in the median county participation rate during the 1989-96 period (see Table 4) and the 2.6-percentage-point decrease in the median county Herfindahl index (see Table 3) during the same period.

In the case of the credit-union participation rate, the dynamic response highlighted by the model in Emmons and Schmid (2000) was in the same direction as the autonomous effect, so they reinforced each other. In the case of the commercial-bank Herfindahl index, however, the effect from the response function worked in the opposite direction from the autonomous changes. Therefore, the autonomous effect of declining values of the commercial-bank Herfindahl index dominated the endogenous effect of increases in the Herfindahl index due to credit-union competition during the period 1989-96. 


\section{CONCLUSIONS}

Credit unions are a growing part of the retail financial landscape in the United States. Creditunion expansion is a controversial issue, particularly among bank and thrift owners and managers. The strength of opposition by these interested parties alone provides some indirect evidence that credit unions are relevant competitors to banks in some market segments of retail financial services. This article provides more direct evidence that is consistent with the notion that credit unions and banks compete directly.

The dynamic theoretical model of competition between banks and credit unions in Emmons and Schmid (2000) makes two predictions. First, an increase in the concentration of the commercialbanking sector of a county in a given year will lead to an increase in the participation rate at occupational credit unions in this county during the next year, all else being equal. In other words, some households respond to increased concentration among local banks by moving accounts to credit unions. Second, an increase in the rate of participation at credit unions in a given year will cause more concentration in the commercial-banking market of the respective county during the next year, all else held constant. Both theoretical predictions are supported by the empirical results presented in this article, suggesting that credit unions, indeed, play a role in local deposit-market competition. These results indicate that commercial banks and credit unions are direct competitors in the local household deposit market.

\section{REFERENCES}

Amel, Dean F., and Timothy H. Hannan. “Establishing Banking Market Definitions Through Estimation of Residual Deposit Supply Equations," Board of Governors of the Federal Reserve System, working paper, 1998.

Berger, Allen N. "The Profit-Structure Relationship in Banking: Tests of Market-Power and Efficient-Structure Hypotheses," Journal of Money, Credit, and Banking (May 1995), pp. 404-31.

, Rebecca S. Demsetz, and Philip E. Strahan. "The Consolidation of the Financial Services Industry: Causes, Consequences, and Implications for the Future," Journal of Banking and Finance (February 1999), pp. 135-94.

, and Timothy H. Hannan. "The PriceConcentration Relationship in Banking," Review of Economics and Statistics (May 1989), pp. 291-99.
Demsetz, Harold. "Industry Structure, Market Rivalry, and Public Policy," Journal of Law and Economics (April 1973), pp. 1-9.

Emmons, William R., and Frank A. Schmid. "Wages and Risk-Taking in Occupational Credit Unions: Theory and Evidence," this Review (March-April 1999a), pp. 13-31. , and . "Credit Unions and the Common Bond," this Review (September/October 1999b), pp. 41-64.

, and _......... "Banks, Credit Unions, and the Dynamics of Competition," Federal Reserve Bank of St. Louis working paper 2000-006A, 2000.

Gilbert, R. Alton. "Bank Market Structure and Competition: A Survey" Journal of Money, Credit, and Banking (November 1984), pp. 617-44.

Greene, William H., Econometric Analysis, $3^{\text {rd }}$ ed., Prentice Hall, 1997.

Hannan, Timothy H. “Market Share Inequality, the Number of Competitors, and the HHI: An Examination of Bank Pricing," Review of Industrial Organization (February 1997), pp. 23-35. , and Nellie J. Liang. "The Influence of Thrift Competition on Bank Business Loan Rates," Journal of Financial Services Research (June 1995), pp. 107-22.

Kwast, Myron L., Martha Starr-McCluer, and John D. Wolken. "Market Definition and the Analysis of Antitrust in Banking," The Antitrust Bulletin (Winter 1997), pp. 973-95.

Nanni, Anthony V. "Consolidation in the Banking Industry: An Antitrust Perspective," in Bank Mergers and Acquisitions, Yakov Amihud and Geoffrey Miller, eds., Kluwer, 1998, pp. 191-206.

Neumark, David, and Steven A. Sharpe “Market Structure and the Nature of Price Rigidity: Evidence from the Market for Consumer Deposits," Quarterly Journal of Economics (May 1992), pp. 657-80.

Prager, Robin A., and Timothy H. Hannan. “Do Substantial Horizontal Mergers Generate Significant Price Effects? Evidence From the Banking Industry," Journal of Industrial Economics (December 1998), pp. 433-52.

Scherer, F. M., and David Ross. Industrial Market Structure and Economic Performance, Houghton Mifflin Company, 1990.

Shaffer, Sherrill. "Competition in the U.S. Banking Industry." Economics Letters (April 1989), pp. 321-23.

. . . . . . . . . . Palgrave Dictionary of Money and Finance, Peter Newman, Murray Milgate, and John Eatwell, eds., Stockton Press, 1992, Volume 1, pp. 414-16.

The World Almanac and Book of Facts 1990. World Almanac Books, 1989. 


\section{REV I E W}

The World Almanac and Book of Facts 1997. World Almanac Books, 1996.

Tirole, Jean. The Theory of Industrial Organization, MIT Press, 1988.

U. S. Treasury Department. Credit Unions, U.S. Government Printing Office, 1997. 


\section{DATASET AND VARIABLES}

\section{The Data set}

We analyze a dataset comprising all federally chartered and federally insured credit unions during the years 1989-96. Before eliminating some counties for some years, due to reasons mentioned bel ow, the credit-union dataset comprised 41,329 observations. The dataset was obtained from the Report of Condition and Income for Credit Unions (NCUA 5300, 5300S), produced by the National Credit Union Administration (NCUA). These reports are issued semiannually in June and December. We used the December data from each year. The business years of the credit unions are on a calendar basis. The flows in the December income statements cover the entire year, whereas the stocks in the balance sheet are end-of-year values.

We concentrate on the following Types of Membership (TOM) groups among occupationally based credit unions: educational; military; federal, state, and local government; manufacturing; and services. This means that we do not include community credit unions, associational credit unions, or corporate credit unions. Lists of TOM classification codes are from the NCUA (Instruction No. 6010.2 , July 28, 1995).

We excluded observations for any of the following reasons:

- Missing TOM codes

- Activity codes other than "active"

- Number of members or of potential members not greater than one; applies to actual and to lagged values

- Nonpositive values for total assets or lagged total assets

- No banks operating in the respective county (or independent city) during the year in question or during the preceding year.

Total assets, number of members, and potential number of members are end-of-year values.

We calculated county-specific Herfindahl indexes as measures of concentration of the local banking market. A Herfindahl index is defined as the sum of squared market shares. We measured market shares as the fraction of total commercialbank and BIF-insured thrift deposits (as of June 30) within a county (or independent city) based on FDIC Summary of Deposits data. These data are available online at $<$ http://www2.fdic.gov/sod/> .

We used population density to control for crosssectional differences across counties. Population density was calculated by dividing the total county population by the total land area of the county (or independent city). Both the county population and land-area data were obtained from the U.S. Census Bureau $<$ http://www.census.gov $>$. The population data are Census Bureau estimates as of July 1 of the corresponding year. The land-area measurements are from the 1990 census.

\section{Definition of Variables}

The county-specific credit-union participation rate was calculated as a weighted average over the participation rates of all credit unions in our dataset. We used the number of potential members to weight the participation rates.

The county-specific participation rates and Herfindahl indexes, which serve as the two endogenous variables, are bounded on the $[0,1]$ and the $(0,1]$ intervals, respectively. This conflicts with the assumption of normally distributed error terms. This is why we applied the logit transformation, In $(y /(1-y))$, where $y$ is the participation rate and the Herfindahl index, respectively, and where In is the natural logarithm. To keep the econometric results easy to interpret, we applied this transformation also to the lagged values of these two variables that served as explanatory variables.

The logit transformation requires the values of the variables to lie within the $(0,1)$ interval. Whereas zero values for the Herfindahl index are not defined, zero values for the participation rate can occur. This happens when there are counties without occupational credit unions (of the TOM codes covered by this analysis). This poses the problem of data truncation, for which we did not control explicitly. During the period 1989-96, about 64 percent of the U.S. counties (independent cities included) 
did not have credit unions of the type we analyzed. There was one observation of a county (FIPS 8047) that did not have a bank during 1988 only (and thus, we could not calculate a lagged-Herfindahl index for 1989).

When the participation rate or the Herfindahl index are used as dependent variables, unit values pose the problem of data censoring (the so-called Tobit problem). Observations of unit values for the Herfindahl index did not occur, but there were 34 cases of unit values for the participation rate. We did not control for this Tobit problem because the number of censored observations was low. Instead, we eliminated these observations from the dataset. We also eliminated two observations of unit values for the lagged Herfindahl index and 35 cases of unit values for the lagged participation rate because these observations represent corner solutions. Because there was some overlap in these 72 cases of unit values, we only needed to eliminate 62 observations (out of a total of 8,496 county-years).

There was a total of 3,141 counties (and independent cities) in the United States during 1996, including 43 independent cities (40 in Virginia) and the District of Columbia. The corresponding number for 1989 was 3,139 (The World Almanac and Book of Facts, 1989, 1996). Overall, our study covers 1,061 counties (and independent cities), which is about 34 percent of the total. There were 117 observations (out of a total of 8,434 county-years), for which there was either no bank in the county (one such observation) or no credit union during a given year or during the preceding year.

Definitions of variables and underlying data sources are listed below. For data taken from the Report of Condition and Income for Credit Unions, produced by the National Credit Union Administration, the relevant item numbers are in brackets.

Dependent Variables. We employed two dependent variables in the regressions:

1) Participation Rate (PARTICIPATION): Number of actual credit-union members [CUSA6091] divided by the number of potential members [CUSA6092]. In the regressions, we use the logit transformation, In $(\mathrm{y} /(1-\mathrm{y}))$.

2) Herf: Sum of squared market shares of commercial banks within a county based on total bank deposits. By definition, the Herfindahl index is greater than zero; its maximum value is one.
Independent Variables. In addition to lagged values of the dependent variables, we used three types of control variables:

1) POPDENS: Population Density, population per square mile in the respective county.

2) State-indicator variables; one of the state-indicator variables was eliminated. We do not report parameter estimates for these variables because of their number and because we do not wish to place any particular interpretation on them.

3) Year-indicator variables; the indicator variable for 1989 was eliminated. 